Agata Smyka

Uniwersytet Ekonomiczny we Wrocławiu

180212@student.ue.wroc.pl

\title{
Determinanty rozwoju turystyki w gminie miejsko-wiejskiej Wleń
}

\section{Streszczenie}

Celem rozdziału jest identyfikacja i ocena kluczowych determinant rozwoju turystyki w gminie Wleń. Autorka wykorzystała głównie wyniki badań ankietowych, analizę danych statystycznych oraz metodę opisową. Analizy wykazały, że ocena wpływu wybranych czynników na rozwój turystyki jest zdaniem turystów zróżnicowana. Podobnie jak ocena walorów i elementów infrastruktury turystycznej oraz aktywności władz gminy Wleń.

\section{Wprowadzenie}

W literaturze przedmiotu występują różne klasyfikacje i hierarchie determinant oddziałujących na tempo i kierunek rozwoju turystyki (m.in. Gaworecki, 2003; Kożuchowski, 2005; Kurek, 2007). Analizy prowadzone na poziomie regionalnym wskazują dwie podstawowe grupy czynników (Kozak, 2008). Pierwsza z nich określa tzw. atrakcyjność turystyczną obszaru, na którą wpływa przede wszystkim infrastruktura turystyczna wraz z elementami warunkującymi dostępność atrakcji turystycznych oraz stan i charakter walorów regionalnych służących rozwojowi turystyki. Druga grupa związana jest natomiast ze sferą regulacji. Istotne miejsce w kształtowaniu gospodarki turystycznej zajmują w niej instytucje i tworzona przez nie polityka rozwoju danego obszaru.

Podjęta problematyka dotyczy aktualnych i ważnych zagadnień z punktu widzenia rozwoju terenów turystycznych, stąd stanowi przedmiot zainteresowania autora.

Celem pracy jest identyfikacja i ocena kluczowych determinant rozwoju turystyki w gminie wiejsko-miejskiej Wleń. Uzupełnieniem opracowania jest krótka 
prezentacja gminy. W rozdziale wykorzystano głównie wyniki badań ankietowych turystów, analizę danych statystycznych oraz metodę opisową.

Opracowanie zawiera wprowadzenie, opis wybranych determinant w oparciu o literaturę, prezentację metodyki badań i wyników badań ankietowych, krótką prezentację gminy Wleń wraz z oceną jej walorów i infrastruktury turystycznej oraz zakończenie.

\section{Wybrane determinanty rozwoju turystyki - ujęcie teoretyczne}

Jednym z najważniejszych, jeśli nie najważniejszym czynnikiem rozwoju turystyki, zwłaszcza obszarów wiejskich, są walory turystyczne ${ }^{1}$. Dzielone są one na walory przyrodnicze i antropogeniczne.

Elementy środowiska naturalnego wpływają na różnicowanie atrakcyjności turystycznej regionów, warunkują zagospodarowanie turystyczne i są podstawowym dobrem turystycznym, które im bardziej unikalne, tym bardziej przyciąga uwagę turystów. Tworzą one podstawę do kreowania odpowiednich produktów w regionie, pozwalają bowiem na właściwą alokację zasobów pozostających w dyspozycji podmiotów turystycznych. W literaturze przedmiotu są różnie definiowane ${ }^{2}$. Autorzy często wskazują na elementy środowiska przyrodniczego przyciągające zainteresowanie turysty, wymieniając mniej lub bardziej szczegółowo jego składowe. Przykładowo Kożuchowski zalicza do nich podłoże skalne, glebę, rzeźbę terenu, florę i faunę, wody powierzchniowe i podziemne, pogodę i klimat lokalny. Naturalne walory są powszechne, lecz różnią się intensywnością występowania w przestrzeni.

Walory antropogeniczne uzupełniają walory przyrodnicze, tworząc efekt synergii. Określane są jako ogół elementów, które wiążą się z działalnością człowieka. Nazywane są również walorami kulturowymi (Kurek, 2007). Zalicza się do nich niematerialne składniki kultury (tradycje historyczne), historyczne elementy materialne oraz elementy kultury współczesnej (Gołembski, 2007).

Udostępnianie walorów turystycznych umożliwia zagospodarowanie turystyczne. Obejmuje ono bazę: noclegową, żywieniową, komunikacyjną i towarzyszącą (tab. 1).

Zaprezentowany $\mathrm{w}$ tabeli 1 podział infrastruktury turystycznej jest $\mathrm{w}$ literaturze przedmiotu niejednoznaczny i może powodować nieścisłości w analizach porównawczych i ocenie poziomu zagospodarowania obszarów.

\footnotetext{
1 Walory turystyczne to wszystkie wartości występujące na obszarze, które stworzyła natura (przyroda), ukształtowała historia i tworzy współczesność, będące przedmiotem zainteresowania turystów (Mazur, 2003).

2 Zobacz m.in.: Gaworecki (2003), Kurek (2007), Wojcieszak (2016).
} 
Tabela 1. Podział i charakterystyka infrastruktury turystycznej

\begin{tabular}{|c|c|c|}
\hline $\begin{array}{c}\text { Infrastruktura } \\
\text { turystyczna }\end{array}$ & Definicja & Charakterystyka \\
\hline $\begin{array}{l}\text { Infrastruktura } \\
\text { podstawowa }\end{array}$ & $\begin{array}{l}\text { Niezbędna } \\
\text { do realizacji } \\
\text { funkcji } \\
\text { turystycznej }\end{array}$ & $\begin{array}{l}\text { Baza noclegowa to m.in.: hotele, motele, kempingi, } \\
\text { pola biwakowe, domy wycieczkowe, schroniska, domy } \\
\text { turysty, pensjonaty } \\
\text { Baza gastronomiczna dzielona jest na: } \\
\text { - zakłady gastronomiczne typu żywieniowego, tj. re- } \\
\text { stauracje, bary uniwersalne, mleczne, szybkiej obsłu- } \\
\text { gi, bistra, jadłodajnie itp. } \\
\text { - zakłady gastronomiczne uzupełniające, tj. kawiar- } \\
\text { nie, bary kawowe, herbaciarnie, winiarnie, cukiernie, } \\
\text { puby } \\
\text { - punkty gastronomiczne, tj. bufety, smażalnie, lo- } \\
\text { dziarnie, pijalnie itp. } \\
\text { Baza komunikacyjna - zalicza się tu m.in.: szlaki lotni- } \\
\text { cze, sieć dróg, linie kolejowe, porty lotnicze, morskie, } \\
\text { stacje kolejowe }\end{array}$ \\
\hline $\begin{array}{l}\text { Infrastruktura } \\
\text { towarzysząca }\end{array}$ & $\begin{array}{l}\text { Uzupełnienie } \\
\text { bazy } \\
\text { podstawowej }\end{array}$ & $\begin{array}{l}\text { Dzielona jest na: } \\
\text { - urządzenia turystyczne - m.in.: kąpieliska, kolejki } \\
\text { linowe, sale sportowe, korty tenisowe, szlaki żeglow- } \\
\text { ne, wyciągi narciarskie, szlaki turystyczne: konne, } \\
\text { piesze, ścieżki zdrowia } \\
\text { - urządzenia paraturystyczne - techniczne uzbrojenie } \\
\text { terenu (sieć elektryczna, wodna, gazowa, kanaliza- } \\
\text { cyjna), sieć handlu detalicznego, usługi (fryzjerskie, } \\
\text { fotograficzne), urządzenia pocztowe, ochrony zdro- } \\
\text { wia, instytucje kulturalne i bezpieczeństwa publicz- } \\
\text { nego }\end{array}$ \\
\hline
\end{tabular}

Źródło: opracowanie własne na podstawie Lijewski i in. (2002).

Do podstawowych podmiotów otoczenia instytucjonalnego, których zadaniem jest wspieranie turystyki, zaliczane są przede wszystkim organy państwa oraz różnego rodzaju instytucje i organizacje pozarządowe, w tym związki i zrzeszenia branżowe oraz stowarzyszenia.

Od działań podejmowanych na różnych szczeblach władzy państwowej uzależnione jest tempo i zakres rozwoju zarówno popytu, jak i podaży turystycznej. Wyrazem aktywności tych instytucji jest określenie celów ekonomicznych, politycznych, kulturalnych i społecznych rozwoju turystyki. Jednym z głównych działań administracji centralnej jest opracowywanie dokumentów wyznaczających priorytety i podstawowe kierunki rozwoju turystyki w kraju. Z kolei samorządy lokalne kształtują warunki dla rozwoju gospodarki turystycznej na własnym obszarze oraz tworzą płaszczyzny współdziałania podmiotów w regionie.

Do najważniejszych instytucji i organizacji wpływających na rozwój turystyki w Polsce należy zaliczyć m.in.: Dział Turystyki w Ministerstwie Rozwoju, Pracy i Technologii, Polską Organizację Turystyki (POT) i jej wojewódzkie oddziały, Polską Izbę Turystyki (PIT), samorządy wojewódzkie, powiatowe i gminne, 
Związek Gmin Wiejskich RP, lokalne i regionalne stowarzyszenia agroturystyczne i turystyki wiejskiej oraz Polską Federację Turystyki Wiejskiej „Gospodarstwa Gościnne".

\section{Metodyka badań}

Badania empiryczne przeprowadzono w 2021 r. na terenie gminy Wleń. Ich celem była identyfikacja wybranych czynników rozwoju turystyki oraz ocena ich realizacji na omawianym obszarze. Badaniami objęto dziewięć z dwunastu sołectw gminy, w tym miasto Wleń. Zastosowano kwestionariusz ankiety. Wykorzystano badania bezpośrednie, które przeprowadzili ankieterzy. Forma ta pozwoliła na większą kontrolę zbieranych danych. W kwestionariuszu wykorzystano pytania zamknięte. Próba badawcza miała charakter losowy. Łącznie w badaniach uczestniczyło 70 turystów, z czego do analizy przyjęto 53 kwestionariusze (tab. 2).

Tabela 2. Charakterystyka badanych turystów

\begin{tabular}{lc}
\hline Płeć & \% badanych \\
\hline kobieta & 53 \\
mężczyzna & 52 \\
\hline Wykształcenie & \\
\hline zawodowe & 10 \\
średnie & 54 \\
$\quad$ wyższe & 36 \\
\hline Miejsce zamieszkania & \\
\hline miasto & 65 \\
wieś & 35 \\
\hline
\end{tabular}

Źródło: opracowanie własne.

Wśród uczestników badań 53\% stanowiły kobiety, a 52\% mężczyźni. Najczęściej były to osoby z wykształceniem średnim (54\%) i wyższym (36\%) oraz mieszkańcy miast (65\%). Materiał empiryczny opracowano metodami statystycznymi, a wyniki przedstawiono w oparciu o procentowy rozkład liczebności.

\section{Prezentacja wyników badania}

W odniesieniu do rozwoju turystyki na obszarach wiejskich duże znaczenie turyści przypisują walorom przyrodniczym i antropogenicznym oraz szlakom turystycznym (tab. 3). Te pierwsze zdaniem prawie 95\% respondentów to czynnik o bardzo dużym lub dużym znaczeniu. Atrakcje turystyczne stworzone przez człowieka bardzo duży lub duży wpływ mają dla prawie $75 \%$ badanych, a szlaki turystyczne to dla prawie $93 \%$ respondentów czynnik o bardzo dużym lub dużym znaczeniu dla rozwoju turystyki. Zagospodarowanie turystyczne terenu, głównie w postaci obiektów sportowo-rekreacyjnych, bazy gastronomicznej i noclegowej, 
to czynniki o dużym lub bardzo dużym wpływie na rozwój turystyki w regionie analogicznie dla prawie $85 \%, 87 \%$ i $63 \%$ badanych.

Tabela 3. Ocena wpływu wybranych czynników na rozwój turystyki na obszarach wiejskich (w\%)

\begin{tabular}{|c|c|c|c|c|c|}
\hline \multirow[b]{2}{*}{ Rodzaj czynnika } & \multicolumn{5}{|c|}{ Wpływ czynnika na rozwój turystyki } \\
\hline & $\begin{array}{l}\text { bardzo } \\
\text { duży }\end{array}$ & duży & średni & niski & $\begin{array}{l}\text { bardzo } \\
\text { niski }\end{array}$ \\
\hline $\begin{array}{l}\text { Przyroda (np. lasy, parki krajobrazowe, woda, } \\
\text { góry) }\end{array}$ & 84,90 & 9,44 & 5,66 & - & - \\
\hline $\begin{array}{l}\text { Atrakcje turystyczne, np. zabytki, kościoły, } \\
\text { muzea }\end{array}$ & 56,60 & 18,87 & 18,88 & 5,65 & - \\
\hline Imprezy kulturalne, sportowo-rekreacyjne & 37,73 & 18,87 & 28,30 & 15,10 & - \\
\hline Baza noclegowa i jej zróżnicowanie & 33,96 & 28,30 & 37,74 & - & - \\
\hline Baza gastronomiczna i jej zróżnicowanie & 41,51 & 45,28 & 13,21 & - & - \\
\hline $\begin{array}{l}\text { Obiekty sportowo-rekreacyjne (np. baseny, } \\
\text { boiska, lodowiska) }\end{array}$ & 54,70 & 30,20 & 15,10 & - & - \\
\hline Dojazd do obszaru, drogi & 18,87 & 15,10 & 41,51 & 24,52 & - \\
\hline Szlaki turystyczne, np. piesze, konne, rowerowe & 60,40 & 32,10 & 7,50 & - & - \\
\hline Władze gminy & 22,64 & 33,96 & 13,21 & 24,53 & 5,66 \\
\hline $\begin{array}{l}\text { Stowarzyszenia lokalne, lokalne grupy } \\
\text { działania }\end{array}$ & 9,43 & 18,87 & 13,21 & 52,83 & 5,66 \\
\hline $\begin{array}{l}\text { Instytucje turystyczne, np. Polska Izba } \\
\text { Turystyki }\end{array}$ & 15,10 & 16,97 & 24,52 & 32,10 & 11,31 \\
\hline
\end{tabular}

Źródło: opracowanie własne.

Badania wykazały również, że zdaniem turystów najniższy wpływ na rozwój turystyki w regionie mają stowarzyszenia lokalne (prawie $60 \%$ oceniło go jako niski i bardzo niski), następnie instytucje turystyczne (43\% wskazań jako niski i bardzo niski) oraz władze gminy (niecałe $31 \%$ wskazań jako niski).

Uzupełnieniem oceny wpływu wybranych czynników na rozwój turystyki na obszarach wiejskich jest niewątpliwie deklaracja znaczenia dla turysty elementów wiejskiej przestrzeni recepcji turystycznej. Wskazuje ona na motywy ich wyborów wypoczynkowych.

Podczas analizy znaczenia dla turysty wybranych charakterystyk wiejskiego obszaru turystycznego istotnych dla przyjazdu do regionu na uwagę zasługują odpowiedzi wskazujące na elementy walorów przyrodniczych (piękno przyrody, cisza i spokój), walorów antropogenicznych (aktywny wypoczynek i aspekt poznawczy) oraz przypisanie wysokiego znaczenia wyżywieniu (tab. 4).

Porównując ocenę wpływu wybranych czynników na rozwój turystyki dokonaną przez turystów z motywami ich wyboru wiejskiej przestrzeni turystycznej, należy zauważyć korelację między wskazanymi determinantami. W obu przypadkach największe znaczenie mają walory przyrodnicze i antropogeniczne oraz zagospodarowanie turystyczne (w tym głównie baza gastronomiczna oraz infrastruktura służąca aktywnemu wypoczynkowi). 
Tabela 4. Znaczenie dla turysty charakterystyk wiejskiego obszaru turystycznego

\begin{tabular}{lccccc}
\hline \multirow{2}{*}{ Możliwości i elementy } & \multicolumn{5}{c}{ Znaczenie } \\
\cline { 2 - 6 } & $\begin{array}{c}\text { bardzo } \\
\text { duże }\end{array}$ & duże & średnie & niskie & $\begin{array}{c}\text { bardzo } \\
\text { niskie }\end{array}$ \\
\hline Cisza i spokój & 15,10 & 32,10 & 24,53 & 11,30 & 16,97 \\
Piękno przyrody & 50,95 & 26,41 & 22,64 & - & - \\
Wyżywienie & 43,40 & 33,96 & 16,97 & 5,67 & - \\
Możliwość aktywnego wypoczynku & 32,10 & 24,53 & 9,42 & 26,41 & 7,54 \\
Wydarzenia kulturalne, sportowe, & 16,97 & 26,41 & 15,10 & 32,10 & 9,42 \\
turystyczne & & & & & \\
$\begin{array}{l}\text { Możliwość interesującego spędzenia czasu } \\
\text { wolnego }\end{array}$ & 58,50 & 26,41 & 13,30 & 1,88 & - \\
$\begin{array}{l}\text { Możliwość poznania m.in. kultury, } \\
\text { zwyczajów }\end{array}$ & 50,94 & 28,30 & 20,76 & - & - \\
\hline
\end{tabular}

Źródło: opracowanie własne.

\section{Walory i infrastruktura turystyczna oraz instytucje wspierające rozwój turystyki w gminie Wleń}

Wleń jest gminą miejsko-wiejską, położoną w południowo-zachodniej części województwa dolnośląskiego w powiecie lwóweckim, na pograniczu Pogórza Izerskiego i Kaczawskiego. W skład gminy wchodzi 1 miasto (Wleń) i 12 sołectw. Gmina zajmuje powierzchnię $86 \mathrm{~km}^{2}$, z czego $94,26 \%$ to grunty rolne i leśne. Gmina charakteryzuje się zróżnicowanym ukształtowaniem powierzchni i w $70 \%$ leży w granicach Parku Krajobrazowego Doliny Bobru, a na jej obszarze znajdują się dwa rezerwaty przyrody (Na Ostrzycy Proboszczowickiej i Góra Zamkowa położony nad miastem Wleń). Oba wchodzą w skład obszarów Natura 2000, pod nazwą Ostrzyca Proboszczowicka oraz Ostoja nad Bobrem (Wleń, 2009; UMiG Wleń 2021).

Wśród atrakcji gminy na szczególną uwagę zasługuje (Wleń, 2009; Wiklik, 2011; UMiG Wleń, 2021):

- Wleński Gródek - to ruiny średniowiecznej warowni, zespół pałacowo-parkowy, kościół pw. św. Jadwigi oraz rezerwat przyrody „Góra Zamkowa”.

- Jezioro Pilchowickie - największy akwen w Sudetach Zachodnich (powierzchnia 240 ha, głębokość przy zaporze ok. 46 m, a długość jeziora 6 km).

- Kolej Doliny Bobru - najpiękniejszy, najbardziej malowniczy odcinek kolei w Polsce. Obecnie nieczynna.

- Pomnik Gołębiarki - zlokalizowany na rynku miasta, a wzniesiony z okazji 700-lecia jego założenia w 1914 r. Główną część pomnika stanowi figura dziewczyny z gołębiem na prawym ramieniu.

Ścieżka św. Jadwigi Śląskiej - trasa około 2 km, którą można pokonać pieszo.

W gminie odbywa się szereg imprez (wg danych GUS w 2018 r. było ich 42, a w 2019 - 29) (GUS, 2021). Niestety jedynie Dni Wlenia mają zasięg krajowy, a nawet międzynarodowy. Większość imprez nie jest też dostępna dla turysty. 
Na terenie gminy Wleń funkcjonują według danych GUS 3 obiekty noclegowe (tab. 5). Dysponują one łącznie 100 miejscami noclegowymi. Nie odzwierciedla to ilości bazy noclegowej w gminie, gdyż działa na jej terenie szereg gospodarstw agroturystycznych i innych obiektów noclegowych. Na stronie gminy podanych jest ich 9, jednak jest ich przynajmniej 16.

Tabela 5. Turystyczne obiekty noclegowe ogółem w gminie Wleń (stan w dniu 31 lipca)

\begin{tabular}{lrrrrrr}
\hline Wyszczególnienie & 2015 & 2016 & 2017 & 2018 & 2019 & 2020 \\
\hline Obiekty & 4 & 4 & 3 & 3 & 3 & 3 \\
Miejsca noclegowe, w tym: & 121 & 122 & 100 & 100 & 100 & 100 \\
Szkolne schroniska młodzieżowe & 41 & 42 & 41 & 41 & 41 & 41 \\
Pokoje gościnne/kwatery prywatne & 0 & 0 & 10 & 10 & 10 & 10 \\
Pozostałe turystyczne obiekty noclegowe & 49 & 49 & 49 & 49 & 49 & 49 \\
\hline
\end{tabular}

Źródło: opracowanie własne na podstawie GUS (2021).

Do gastronomii na stronie gminy zaliczona została jedynie Gołębiarka Cafe kawiarnia, która mieści się na wleńskim rynku. Na terenie gminy działa jeszcze bar przy zaporze w Pilchowicach.

Przez terytorium gminy przebiega pięć szlaków turystycznych: szlak Via Cervimontana - prowadzi na koniec świata, niebieski Europejski Szlak Długodystansowy [E-3], czarny szlak prowadzący z Marczowa do Płoszczycy, zielony Szlak Zamków Piastowskich, żółty szlak (Szlak Wygasłych Wulkanów) biegnący z Nowego Lądu do Świerzawy oraz Euroregionalny Turystyczny Szlak Rowerowy „Dolina Bobru” [ER-6].

Do elementów infrastruktury paraturystycznej gminy należy: Ośrodek Kultury, Sportu i Turystyki, Miejsko-Gminny Ośrodek Pomocy Społecznej, Urząd Pocztowy, Ośrodek Zdrowia, apteka, 4 sklepy spożywcze/przemysłowe, w tym jeden supermarket. W gminie jest również jedno targowisko o powierzchni sprzedażowej $90 \mathrm{~m}^{2}, 5$ boisk, 8 siłowni zewnętrznych i innych obiektów oraz 3 biblioteki.

W gminie w rozwój turystyki zaangażowane są przede wszystkim władze gminy oraz Partnerstwo Izerskie Stowarzyszenie LGD. Z innych organizacji można wymienić Stowarzyszenie „Modrzewie”, które zajmuje się głównie rozwojem wsi agroturystycznej Modrzewie.

Władze gminy Wleń w szerokim zakresie w porównaniu z możliwościami starają się aktywnie rozwijać turystykę w gminie. W 2007 r. przeprowadzono modernizację dwóch tras turystycznych (Radomice-Klecza i Pilchowice-Zapora-Strzyżowiec). W latach 2000-2011 wyremontowano i zagospodarowano Zamek Lenno (wpisany do rejestru zabytków). Władze gminy sukcesywnie wzbogacają ofertę turystyczną, głównie w zakresie imprez turystycznych. Prowadzone są również w sposób ciągły działania promujące gminę.

Władze lokalne wykorzystują zróżnicowane działania mające na celu aktywizację turystyki w gminie, w tym m.in. intensywnie pozyskują środki finansowe na realizację zaplanowanych działań oraz wykorzystują instrumenty organizacyjne, współpracując z innymi podmiotami z regionu, w tym z Euroregionem Nysa oraz Partnerstwem Izerskie Stowarzyszenie LGD. To ostatnie aktywnie przyczynia 
się do rozwoju turystyki na podlegającym mu obszarze, w tym na terenie gminy Wleń. Działania LGD koncentrują się na wzbogacaniu i poprawie infrastruktury turystycznej i paraturystycznej regionu (np. wytyczenie i oznakowanie ok. 100 km szlaków konnych), oferty turystycznej, odnowie zabytków architektury (rewitalizacja obiektów i miejsc należących do dziedzictwa przyrodniczego w latach 2016-2018), podnoszeniu wiedzy i umiejętności mieszkańców Pogórza oraz promocji obszaru i jego walorów turystycznych i podmiotów prowadzących działalność w sferze turystyki (np. wydanie katalogu ofert weekendowych wypoczynku na Pogórzu Izerskim).

Badania pozwoliły na ocenę omówionych wyżej czynników rozwoju turystyki w prezentowanej gminie. Ocenie poddano szereg elementów obszaru, w tym głównie walory i infrastrukturę turystyczną, oraz elementy będące wynikiem działań władz gminnych i innych organizacji (tj. dbałość o zabytki oraz czystość i porządek).

Analizując wypowiedzi respondentów, należy zauważyć, że w gminie najlepiej oceniona została „przyroda” (prawie 93\% ocen dobrych lub bardzo dobrych), następnie wyżywienie w obiektach noclegowych (prawie $88 \%$ wskazań na ocenę dobrą lub bardzo dobra) oraz możliwości uprawiania turystyki aktywnej (prawie $70 \%$ ocen dobrych lub bardzo dobrych).

Tabela 6. Ocena istniejących w gminie Wleń warunków do świadczenia usług turystycznych (w \%)

\begin{tabular}{|c|c|c|c|c|c|}
\hline \multirow[b]{2}{*}{ Elementy oceny } & \multicolumn{5}{|c|}{ Ocena } \\
\hline & $\begin{array}{c}\text { bardzo } \\
\text { dobra }\end{array}$ & dobra & średnia & niska & $\begin{array}{c}\text { bardzo } \\
\text { niska }\end{array}$ \\
\hline Zakwaterowanie & - & 41,5 & 35,83 & 22,67 & - \\
\hline Wyżywienie ogólnodostępne & - & - & - & 52,84 & 47,16 \\
\hline Wyżywienie w obiektach noclegowych & 49,10 & 39,60 & 11,30 & - & - \\
\hline $\begin{array}{l}\text { Możliwości uprawiania turystyki aktywnej, } \\
\text { np. szlaki piesze, rowerowe, konne, wodne }\end{array}$ & 35,83 & 33,96 & 22,67 & 7,54 & - \\
\hline Infrastruktura do wypoczynku nad wodą & - & 5,67 & 20,74 & 30,19 & 43,40 \\
\hline $\begin{array}{l}\text { Obiekty sportowo-rekreacyjne (np. baseny, } \\
\text { boiska) }\end{array}$ & - & - & 28,30 & 37,74 & 33,96 \\
\hline Przyroda, ukształtowanie terenu, lasy itp. & 67,93 & 24,53 & 7,54 & - & - \\
\hline Atrakcje do zwiedzania, np. zamki & 20,74 & 18,87 & 28,32 & 24,53 & 7,54 \\
\hline Imprezy kulturalne, sportowo-rekreacyjne & & 7,54 & 33,97 & 37,75 & 20,74 \\
\hline $\begin{array}{l}\text { Infrastruktura drogowa (drogi, dostępność } \\
\text { atrakcji, parkingi) }\end{array}$ & - & 26,41 & 33,96 & 20,74 & 18,87 \\
\hline Dbałość o zabytki (oznakowanie, renowacja) & - & 32,07 & 52,84 & 15,09 & - \\
\hline Czystość i porządek & - & 41,52 & 41,52 & 7,54 & 9,42 \\
\hline
\end{tabular}

Źródło: opracowanie własne.

Działania władz gminnych i innych podmiotów zostały ocenione generalnie na poziomie średnim i dobrym. 
Najniżej turyści ocenili zagospodarowanie turystyczne w zakresie bazy gastronomicznej ogólnodostępnej (100\% ocen niskich lub bardzo niskich), infrastruktury umożliwiającej wypoczynek nad wodą (prawie $74 \%$ ocen niskich), zagospodarowania w obiekty sportowo-rekreacyjne (prawie $72 \%$ ocen niskich) oraz infrastruktury drogowej (prawie $40 \%$ ocen niskich). Nisko oceniono również imprezy kulturalne i sportowo-rekreacyjne.

W gminie, zdaniem turystów, należy przede wszystkim poprawić i/lub rozwinąć określone elementy zagospodarowania turystycznego (prawie 55\% wskazań). Jeżeli wszystkie udzielone odpowiedzi w tej grupie uznane zostaną za $100 \%$, to nakładów wymaga głównie rozwój: bazy kulturalnej, sportowej i rekreacyjnej (ponad 65\%), bazy gastronomicznej (prawie 59\%) oraz dostępności komunikacyjnej, w tym głównie poprawa stanu dróg i tworzenie parkingów przy atrakcjach (niecałe 42\%).

Można zauważyć, że powinna również wzrosnąć liczba obiektów sportowo-rekreacyjnych (prawie 36\% badanych) oraz zostać rozbudowana infrastruktura zwiększająca dostępność wypoczynku nad wodą (prawie co trzeci badany wskazuje na jej rozwój). W odniesieniu do tej ostatniej należy zauważyć, że gmina ma zasoby wodne, które można w większym stopniu udostępnić turystom. Obecnie są one wykorzystywane w niewielkim zakresie - zbiornik wodny w Pilchowicach jest niezbyt zagospodarowany, podobnie jak rzeka Bóbr płynąca przez teren gminy.

\section{Zakończenie}

Zestawienie oceny wpływu wybranych czynników na rozwój turystyki na obszarach wiejskich, ich znaczenia dla turysty z oceną istniejących $\mathrm{w}$ gminie Wleń warunków do świadczenia usług turystycznych pozwala na sformułowanie m.in. następujących wniosków:

1. Podstawowe czynniki rozwoju turystyki na obszarach wiejskich to zdaniem turystów przede wszystkim: walory turystyczne (przyrodnicze i antropogeniczne) oraz wybrane elementy zagospodarowania turystycznego, w tym głównie: szlaki turystyczne, obiekty sportowo-rekreacyjne, baza gastronomiczna i w mniejszym stopniu noclegowa.

2. Istotne znaczenie dla przyjazdu turysty do regionu mają: elementy walorów przyrodniczych (piękno przyrody, cisza i spokój) i antropogenicznych (aspekt poznawczy) oraz baza gastronomiczna.

3. W gminie Wleń najlepiej oceniona została „przyroda”, następnie wyżywienie w obiektach noclegowych oraz możliwości uprawiania turystyki aktywnej. Najniżej turyści ocenili zagospodarowanie turystyczne w zakresie bazy gastronomicznej ogólnodostępnej, infrastruktury umożliwiającej wypoczynek nad wodą, infrastruktury drogowej oraz obiektów sportowo-rekreacyjnych.

4. Walory turystyczne (zwłaszcza przyrodnicze) mają duże znaczenie dla rozwoju turystyki, przyjazdu do obszaru oraz zostały wysoko ocenione w gminie. Podobnie wygląda ocena elementów zagospodarowania turystycznego, jakim 
są szlaki turystyczne. Z kolei duże znaczenie ma infrastruktura gastronomiczna oraz obiekty sportowo-rekreacyjne, które otrzymały niskie noty w gminie.

5. Zdaniem respondentów stosunkowo niewielki wpływ na rozwój turystyki w regionie mają działania stowarzyszeń lokalnych, instytucji turystycznych oraz władze gminy. Działania wspomnianych instytucji zostały na terenie gminy Wleń ocenione przez turystów na poziomie średnim i dobrym.

6. Podejmowane przez lokalne władze oraz inne organizacje funkcjonujące na terenie gminy działania w zakresie turystyki dotyczą różnych aspektów wpływających na rozwój turystyki, w tym m.in.: zagospodarowania i ochrony walorów przyrodniczych i antropogenicznych, aktywizacji podmiotów gospodarki turystycznej, promocji własnego regionu oraz wzbogacania jego oferty turystycznej. Stosunkowo niska ocena tego czynnika rozwoju turystyki w gminie może wynikać przykładowo z nieznajomości działań prowadzonych przez te instytucje.

Dogłębna analiza porównawcza oczekiwań turystów w zakresie realizacji czynników rozwoju na obszarach wiejskich z pewnością pozwoliłaby na lepsze ich wykorzystanie i dopasowanie do potrzeb odwiedzających, a tym samym wzrost atrakcyjności turystycznej wskazanych regionów.

\section{Literatura}

Gaworecki W. (2003). Turystyka. PWE, Warszawa.

Gołembsk, G. (2006). Kompendium wiedzy o turystyce. PWN, Warszawa.

GUS (2021). Główny Urząd Statystyczny (www.bdl.stat.gov.pl; dostęp: 5.01.2021).

Kozak M.W. (2008). Koncepcje rozwoju turystyki. Studia Regionalne i Lokalne, 1(31): 18 (www.studreg.uw.edu.pl).

Kożuchowski K. (2005). Walory przyrodnicze w turystyce i rekreacji. Wyd. Kurpisz, Poznań.

Kurek W. (2007). Turystyka. PWN, Warszawa.

LGD (2021). Partnerstwo Izerskie. Stowarzyszenie LGD (www.lgdpartnerstwoizerskie.pl; dostęp: 6.01.2021).

Lijewski T., Mikułowski B., Wyrzykowski J. (2002). Geografia turystyki Polski. PWE, Warszawa.

UMiG Wleń (2021). Urząd Miasta i Gminy Wleń (www.wlen.pl; dostęp: 5.01.2021).

Urząd Miasta i Gminy Wleń (2009). Wleń. Już nie zginiesz w naszej gminie. Przewodnik po gminie Wleń. IMAGO.

Wiklik C. Izerskie klimaty. AD REM, Jelenia Góra.

Wojcieszak M. (2016). Zróżnicowanie walorów przyrodniczych na wybranych obszarach metropolitalnych Polski. Cz. 1. Uniwersytet Przyrodniczy w Poznaniu, Poznań.

Zamek Wleń (2021). Zamek Wleń (Lenno) (zameklenno.pl; dostęp: 5.01.2021). 


\section{Determinants of tourism development in the urban-rural community of Wleń}

The aim of the article is to identify and evaluate the essential determinants of tourism development in Wlen. The article uses mainly survey results, statistical data analysis, a descriptive method and document analysis. The conducted analyses showed that according to tourists the valuation of selected factors on tourism development is varied. Similarly, the evaluation of the values and elements of tourist infrastructure and the activity of the authorities of Wleń community.

Translated by Agata Smyka 